\title{
Embodied Cognition, affects and language comprehension
}

\section{Theoretical basis and (literary-)didactic perspectives of a physically- emotionally grounded model of understanding}

\section{Johannes Odendahl ${ }^{1}$}

Published online: 14 August 2020

(C) The Author(s) 2020

\begin{abstract}
Our main considerations take as a starting point the educational policy demand for a model of competence of text comprehension, which should make it possible to measure and systematically increase comprehension accomplishments and competences. The approach of classical cognitive psychology appears particularly suitable for this purpose, which determines comprehension as a rule-guided transfer of a sign complex into a mental representation. However, such representationalism tends to be aporetic in character. A way out of this problem is offered by recent concepts of understanding from the area of Embodied Cognition, according to which all mental operations are embedded in physical interaction processes. Comprehension means, in this sense, letting physical primary experiences be reproduced in a trial-action fashion. This approach is, in this paper, reconsidered in relation to the role of subjectivity and affect: Physical experiences are meaning-generating because they exhibit a subjectively perceived affective valence between pleasure and suffering. The beginning of all understanding therefore is to be located within the emotional sphere.

Such a conception of understanding is supposed to have a considerable impact upon language- and literature teaching in schools. For example, training of reading skills should always be embedded in body-bound experiences. Moreover, learning and understanding both mean cultivating an alert ear for affective undertones, needs and irritations, which might even lead to drawing the curricular benchmarks and competency targets into question. Finally, as art and literature establish areas of freedom and play, literature teaching, especially, needs to be founded on affective awareness, discursive openness and proceeding voluntariness.
\end{abstract}

Keywords Language comprehension - Literary education - Embodied cognition - Aesthetic learning $\cdot$ Affects and emotion

Johannes Odendahl

johannes.odendahl@uibk.ac.at

Extended author information available on the last page of the article 


\section{Introduction}

The phenomenon of understanding written and oral discourses has always formed the core of native language teaching in schools and, therefore, of academic German didactics. Students should learn to adequately understand the statements and intentions of their fellow communicators, to be able to read a wide variety of texts with pleasure and appreciation, and to find their way in a world saturated by text - doing so with an alert understanding. German didactic interest in the phenomenon of understanding has received a noticeable boost as a result of the turn towards competence and output-orientation in the education system. When, after the first PISA study, it was requested of didactics experts that they submit tiered models for the development and structure of domainspecific competences (cf. Klieme et al. 2003), experts in reading- and literary didactics were also confronted with the task of modelling text comprehension in terms of a measurable and improvable, hierarchically-tiered competency that could be divided into sub-dimensions. For the implementation of this task, all existing concepts of understanding were not equally suitable; hermeneutic, deconstructivist, or phenomenological theory may even reinforce a skeptical attitude in view of the endeavour to measure comprehension performance and to systematically increase it.

Concepts from cognitive psychology, on the other hand, have gained considerable significance in reading- and literary didactic modelling of text comprehension (cf. Rosebrock and Nix 2008; Winkler 2011; Zabka 2012). Here, text comprehension is understood as the reader-side construction of a mental model into which textual information and individual pre-knowledge are incorporated. As long as the focus of research lies in determining the quality of text comprehension, this conceptualization turns out to be extremely effective: In a mental model formed by the reader, the individual comprehension of the text should manifest itself in a reliable manner. For diagnostic purposes, it would then be necessary to retrieve this mental model by suitable test procedures, and then to contrast it with the original text (or authorized models thereof).

If using the concept of comprehension of classical cognitivism theory thereby means a step toward the educational policy demand of reading measurability and operability, this certainly does not yet mean treating the phenomenon of comprehension in a theoretically satisfactory way. This is because comprehension might be something more - and something different - than rule-based mental model design, and its quality might not always be able to be measured and improved. If, for example, it was said that two people understand each other well or poorly; that someone feels understood by a fellow human being and another perhaps no longer understands the world around them, then such term usage indicates that the phenomenon of comprehension is not least - and perhaps even in the first place - an emotional, affective event. The following remarks are intended to support this view. After a brief summation of the concept of comprehension in classical cognitive psychology, newer concepts of Embodied Cognition will be applied, which will then be further developed with regard to the significance of the affective element - before certain didactic consequences will be drawn from a concept of comprehension that is bound to the body and to the affects. 


\section{Comprehension as mental model construction: On a cognitive-psychological concept of text comprehension}

Shortly after the first PISA study, Richter and Christmann (2002) published a research review on reading comprehension, which had a major influence on the further development of literary didactic theory. They were guided by a model of text- and reading comprehension developed by cognitive psychologists van Dijk and Kintsch (1983) in the early 1980s. Following their example, Richter and Christmann distinguish five stages of the reading comprehension process (cf. Richter/Christmann 2002, p. 28), which, on the one hand, should be thought of as hierarchically-tiered, but which, on the other hand, are constantly intertwined during reading comprehension (cf. ibid., p. 34). This takes as a starting point the (1) "construction of a propositional text representation", ${ }^{1}$ which primarily means the recognition of letters and words, as well as the linking of individual terms to form entire sentences (propositions); moves on to (2) "local coherence construction", 2 which is the process of combining several sentences (propositions) to form overarching contexts of meaning; and finally, within the framework of (3) "global coherence production"3 - also making use of the reader's preknowledge - forms "macro-propositions", ${ }^{4}$ into which the information that is read in the text is compressed. In the (4) "construction of superstructures", 5 knowledge of text type conventions plays a special role, and the "recognition of rhetorical strategies" 6 also includes pragmatic objectives of the text in connection with its argumentative-rhetorical structure.

When these stages of word processing are completed more or less successfully, a socalled mental model or situational model (named after a possible 'situation' that a text exposes) is stored in the reader's mind as a product of comprehension:

This interactive interplay finally leads to an analogous, content-specific and accessible representation of the facts described in the text, which contains text information and pre-knowledge in an integrated form and is detached from linguistic structures. It is referred to as situational model or mental model [...] and represents the final result of the processing procedure. ${ }^{7}$

From a literary didactic perspective, this concept, which primarily relates to the understanding of factual texts, is unsatisfactory in several respects. The idea that, in a literary text, exactly one "fact" is described, which even merits the definite article, represents, in view of the genre-typical ambiguity, an exception rather than a rule; for a similar reason, one would hardly want to speak here of the "final result of the processing procedure", since Umberto Eco's notion of an "unlimited semiosis" (Eco

\footnotetext{
1 “Aufbau einer propositionalen Textrepräsentation”, ibid., p. 28.

2 "Lokale Kohärenzbildung", ibid.

3 “Globale Kohärenzherstellung", ibid., p. 31.

4 “Makropropositionen", ibid., p. 32.

5 "Bildung von Superstrukturen", ibid., p. 33.

6 "Erkennen rhetorischer Strategien", ibid., p. 34.

7 "Das interaktive Zusammenspiel mündet schließlich in eine analoge, inhaltsspezifische und anschauliche Repräsentation des im Text beschriebenen Sachverhalts, die Textinformationen und Vorwissen in integrierter Form enthält und losgelöst ist von sprachlichen Strukturen. Sie wird als Situationsmodell bzw. mentales Modell [...] bezeichnet und stellt das Endresultat des Verarbeitungsprozesses dar.” (ibid.)
} 
1976, p. 69) should be particularly true of literary reception; literary comprehension should, moreover, not be completely "detached from linguistic structures" - after all, the aesthetic element would be completely lost.

Certainly, the cognitive-psychological model of comprehension could be modified with regard to the reception of literary texts - for example, by taking into account the constitutive ambiguity or the intrinsic value of linguistic structures through the assumption of multiple mental models; or by contouring mental model construction as a potentially incompletable process in the spirit of Eco, as a permanent mental construction site, so to speak. ${ }^{8}$ However, this would not affect the basic assumption that understanding means building mental representations. In classical cognitive psychology, a text is regarded as understood - appropriately or incorrectly — precisely when a recipient has created a model of what is said in the text on the basis of suitable mental operations and has stored it in their brain. But that means nothing other than that, in the process of comprehension, they have replaced one set of signs with another, albeit a mental one. From a conglomerate of phonetic or graphemic signs - i.e., the text in its phonetic and written structure - they have produced a mental meta-sign through the application of thought algorithms: the mental model. What is 'understood', however, still remains a sign, regarding which it would now be necessary to ask again how it is actually understood; and by whom; and where it is to be found, anyway. Reading comprehension means building mental models - that much is clear; but how does one read and understand mental models? Where exactly does one find them? And what kind of entity is it that reads and understands them?

It turns out that the representationalist view of text comprehension is thoroughly aporetic in nature. One, physical, sign is replaced by another, mental one. But the phenomenon of comprehension is not explained in any way and has only shifted by one position. Just as the translation of a text into another language does not help those who do not speak either language, so, too, does the idea of understanding as a process of transforming a text into a mental model structure fail to make it clear by which clue element the final comprehension of this structure is made possible. The cognitivepsychological representationalistic model of comprehension does not provide a solution to the problem of understanding and offers only a metaphor instead of an explanation; because no one, not even a neurophysiologist, has yet seen the mental model.

To be fair, it should be acknowledged that the aporetic structure of representationalism does not only affect cognitive psychology. Hermeneutics since Schleiermacher have already been working on this problem, which appears clear enough from the figure of thought of the hermeneutic circle. It was also Schleiermacher who equated comprehension with interpretation ("Das Auslegen unterscheidet sich von dem Verstehen durchaus nur wie das laute Reden von dem innern Reden." ["Interpretation differs from comprehension only as speaking out loud differs from speaking inwardly"]), cf. Schleiermacher 1977, p. 343), which amounts to conceiving comprehension as the inward vocalization of an interpretative text. But then, what is understood still remains a text - and thus a complex of signs. Ultimately, however, semiotic representationalism has its roots in Cartesian-style epistemology: If, for Descartes, the thinking

\footnotetext{
${ }^{8}$ In this regard, Thomas Zabka (2012) has made an adaptation for literary comprehension. Since the 1990s, cognitive-psychological research has tended to postulate multi-dimensional situational models (cf. Christmann 2010, p. 170).
} 
ego always receives knowledge of its outside world only through mental representations, it is completely enclosed in a cosmos of signs, from and into which no path leads - neither one of direct physical touching, nor one of affective being touched.

\section{Comprehension as a body-bound phenomenon: Approaches of Embodied Cognition}

A possible way out of the aporetic circle of representationalism is offered by more recent scientific approaches of various provenances, which operate under the collective term of an Embodied Cognition. Their common basis is arguably the idea that the generation of meaning, and comprehension are contingent on physical experiences. This mindset is fed by older traditions such as American pragmatism or that of a bodyrelated phenomenology in the sense of Merleau-Ponty; it has also received important input from advances in neurophysiological research, in particular the discovery of socalled mirror neurons. If, as the now canonical experiment by di Pellegrino et al. (1992) was able to show, a certain group of neurons in the pre-motor cortex of a primate fires whenever the test animal executes the movement of grasping; but also whenever it merely observes this movement - carried out by another - then the conclusion is obvious that the observation of a grasping movement implies an understanding of action that is bound to the body. The act of grasping something is understood as grasping holistically, as the observer mentally follows the act of grasping by way of trial. To understand something as something would therefore come down to doing this thing oneself in the mind. This should also apply to language comprehension (for empirical evidence, see i.e. Pulvermüller 2008). To understand a term like 'grasping' would then mean to perform a trial action - a mental grasp. ${ }^{9}$

The driving forces of Embodied Cognition include psycholinguists such as George Lakoff and Mark Johnson, who presented an influential model of metaphor comprehension as early as 1980. Johnson has since systematized this approach and has developed it into a body-bound theory of language and epistemology (cf. Johnson 1987, 2007). The title of his monograph, published in 1987, expresses its core ideas clearly: The Body in the Mind. The Bodily Basis of Meaning, Imagination, and Reason. According to this study, the mind appears to be fundamentally determined by the body insofar as it always makes use of so-called image schemata when forming concepts. For example, there is a "container schema" (Johnson 1987, p. 39), which defines and bundles basic ideas of an inside and an outside space, of containment and exclusion. Such morphological schemes of imagination, it is argued, derive from physical experiences in dealing with the environment; which are then also metaphorically transferred to areas which may themselves abstract far from physical interactions - areas of logical thinking and argumentation (cf. Johnson 2007, p. 19ff.). An expression such as 'the objection made her lose her train of thought', which depicts a rather abstract mental internal event, would thus be understood through recourse to physical experiences with the inside and outside worlds: Something - namely the objection - enters from the outside into a previously protected inner area (which is marked with the term thought as

\footnotetext{
${ }^{9}$ For more detailed conclusions from the mirror-neuron phenomenon regarding language comprehension, cf. Della Putta 2018.
} 
an enclosed and held-together sphere) and thereby makes a person lose, i.e., exit, this previously untouched inner state. Johnson argues that all of this is understandable only because language users have had sufficient experience with the inner and outer worlds - with the entry of a disruptive factor or being forced to exit a state (cf. Johnson 1987, p. 34ff.). Metaphors generated spatially and physically thus constitute conceptual thinking; cognitive operations can be traced back to primary physical experiences of inside and outside, top and bottom, pressure and yielding, outset, journey and destination. Therefore, according to this theory, even the most abstract intellectual speculation is ultimately tied to a physical sensation, and all comprehension of linguistic expressions has a foundation in experiences of physical contact with the world (cf. Johnson 1987, pp. 65ff.; Johnson 2007, pp. 112ff.).

\section{Further developments of Johnson's "embodied" concept of cognition: On the role that subjectivity, intuition and affects plays in comprehension}

Therefore, physical experiences constitute meaning. Understanding language does not mean processing one sign into another and storing it mentally; but, stimulated by a sign, to undertake an associated trial action in the mind. ${ }^{10}$ The key to the formation of meaning, and understanding of meaning is - to follow the premises of Embodied Cognition - to search nowhere else but within the body; or, more precisely: within body-bound experience.

This latter specification seems not insignificant. A mere, empirically given, body, be it a cube, a sphere or any other structure, at first contributes nothing to the generation of meaning. Rather, it is the body-bound experiences with such objects that are important, and again more precisely: it is the experiences of ' $m y$ ' body with these objects that create meaning. Although Mark Johnson vehemently resists the assumption of a transcendent subject-ego (cf. Johnson 2007, p. 58 and passim), his wording betrays much of this deeply subjective origin of sense and meaning, even if he prefers using the first person plural to conceal it: it is always "our bodies" (Johnson 1987, p. XIV), "our bodily experiences" (ibid. p. XX), and "our bodily interactions with our environment" (Johnson 2007, p. X) which are found at the beginning of all meaning formation. This 'my-ness' and 'our-ness' of experience therefore seems to play at least as large a role as being 'bodily'. Apparently, meaning and meaningfulness always only take place where a perceptive, sentient subject is involved. Which is also why one will intuitively deny a word processing (or even a text translating) computer's ability to actually comprehend the text in any way.

But what is it that gives 'my' physical experience such a decisive role in generating meaning? Evidently, the receptivity of my body towards affectively characterized sensations, and its irritability towards pleasure and pain. What creates meaning is first and foremost that which hurts me or does me good. A few examples related to Johnson's container schema, i.e. from the semantic field of inner and outer world,

\footnotetext{
${ }^{10}$ Cf. Sadoski 2018, p. 333: "One commonality in embodied theories is the rejection of any form of abstract, amodal mental representation, and ibid., p. 337: "Embodied language comprehension is the simulated completion of acts of which the words are the first incipient motions."
} 
may illustrate this. Imagine the following situations as vividly as possible: finding shelter from the rain during a thunderstorm - needing to pass by a dog sitting in its doghouse that's known to bite - being locked in and unable to get out - being locked out and not allowed back in - being in a room with a friendly/desired/unloved person - having something valuable in your pocket - having lost something valuable from within your pocket and not finding it - getting lost and not finding the way homefinding yourself safe from someone who has been following you, all the while throwing things at you or ridiculing you.

All these situations are affectively grounded and therefore of high subjective significance, both in a positive and negative sense. Interestingly, however, it is precisely the changing quality of the inner and outer worlds that gives the situation its affective value. Being safe — excluded or even rejected — being exposed to danger knowing that a source of danger is present or absent - sharing an inside space with another and thereby feeling a sense of closeness (that may be affectively charged in different ways) - salvaging and cherishing something: these are all archaic experiences within the inner and outer worlds that generate meaning. However, meaning is not given to them primarily because they are physically mediated, but because they are affectively charged. But the more intense the affective penetration is, the more profound the formation of meaning would result. What the inner and outer worlds actually mean and what they are capable of meaning is what one learns from such experiences. And perhaps the meaning-generating primordial experience of being on the outside and no longer on the inside is the moment of birth.

So the affective element originally gives meaning to the experiences made in one' $\mathrm{s}$ own body - nothing else can do the same. Meaning, and therefore comprehension, are conveyed physically; they are conveyed through 'my' body, the body of a subject of perception and sensation; and they have their reason in the affective, painful and pleasurable, emotionally charged experience of a physical encounter.

\section{Towards a model}

If the formation of meaning has its origin in affectively shaped experiences, then all comprehension of meaning must also be emotionally grounded. Comprehension was characterized above according to the premises of an Embodied Cognition as mental trial actions. With regard to the above-mentioned situations from the semantic realm of the inner and outer worlds it should be added: comprehension is a mental trial action, a mental re-enactment and experiencing. It has also been said that these actions and experiences originally derive meaning from the pleasant or unpleasant quality of those situations. The subjective feelings of "Lust und Unlust" (pleasure and displeasure), to use a term from Kant's Critique of Judgment (Kant 1992, p. 85), is thus found in the spring of all meaning formation. At the beginning of comprehension is the emotion. It seems plausible to assume that this is both phylogenetic and ontogenetic: the earliest contents of consciousness are likely to have had a 'good for me - hurts me' kind of structure. Accordingly, it can be assumed that all comprehension of the world, of actions, and of language refers back to an affective foundation and, however attenuated, will always resonate with primary experiences. 
In terms of the language and reading comprehension, which our reflections took as a starting point, the following picture would result: phonemic or initially graphemic sign complexes are decoded; they are decoded by evoking mental trial actions and experiences in the subject of comprehension (for which the prerequisite is that the subject has learned certain linguistic conventions of sign use); these trial actions and experiences are based on body-bound primary experiences, which in turn derive their first and decisive meaningfulness from subjective-affective valence. All language understanding, even the most abstract and the most mediated, refers back to physical experiences that ultimately receive their meaningfulness from subjective feelings of pleasure and suffering.

In the context of my interest in literary comprehension, I recently attempted to graphically depict this origin of language comprehension from body-bound interactions and affects. The corresponding diagram is given here, after a few arguably necessary explanations.

The assumption that all formation of meaning and all comprehension are affectively 'grounded' is taken into account in the figure by the fact that an affective comprehension fills the framework of the diagram and encompasses and penetrates the other dimensions of comprehension. As explained above, it is based on Kant's feelings of pleasure and displeasure. Originally, these provide the meaningfulness of body-bound experiences of the subject with a physical or personal environment. In the model, this second level is called pragmatic comprehension. Here, comprehension is both the understanding of action in the sense of American pragmatism (and Embodied Cognition), as well as communicative understanding in the sense of pragmatics or speech act theory (according to which an utterance is understood as an appeal, as the self-utterance of a speaker or as a relationship message). Pragmatic comprehension, in turn, is the base of, penetrates, and presupposes language comprehension in the narrower sense, which is tied to conventional symbols. It is referred to here as referential understanding, making use of a term by Roman Jakobson (1960). It implies the reference of a sign to an object suggested by linguistic convention; this object may be situated in the real environment of the understanding subject, but it can also be a mentally available term. In any case, according to what was said above, referential comprehension triggers a mental trial interaction with the object of the understood, which can imply both action and the suffering of an action. The 'object' is therefore the counterpart only from the point of view of epistemology, it can nevertheless 'approach' the subject of comprehension and affect it.

To appropriately explain the essence and aim of the model of literary comprehension, here called poetic understanding after Jakobson, would mean going beyond the scope of this paper. Suffice it to say that for Jakobson, the poetic function of linguistic communication consists in breaking up the conventional assignment of signs to objects, which is otherwise habitual, by experimenting with the sign structure. A poetic understanding derived from this amounts accordingly to experiencing the fundamental discrepancy between signs and the signified, thereby allowing one to play with signs and meanings, to abolish the pragmatic purposefulness of all speaking and acting in a playful way, and finally, to transcend pleasure and suffering cathartically (cf. Odendahl 2018, pp. 126 f.; p. 116) in Fig. 1. 


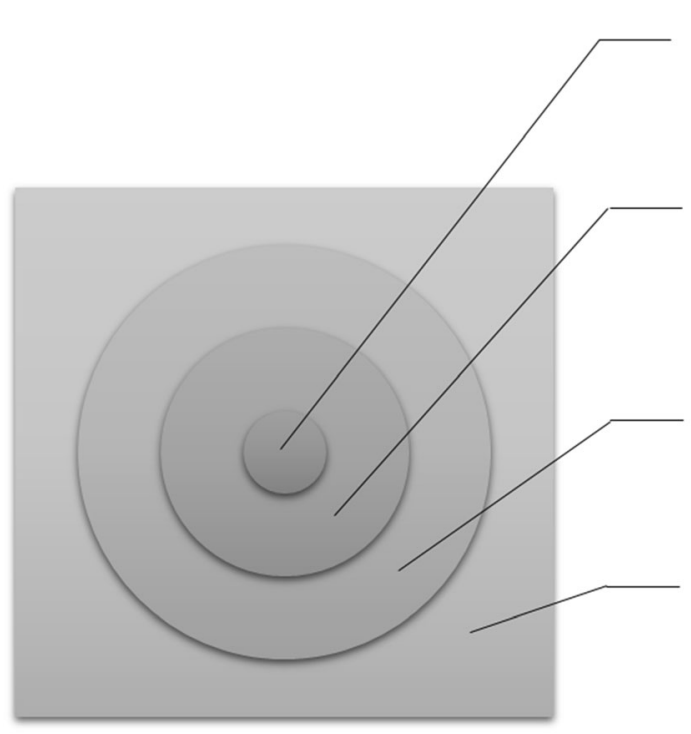

poetic

understanding

Based on experiencing

the discrepancy

between sign and object

referential

understanding

Based on the

assignment of signs to

mental or real objects

of interaction

pragmatic

understanding

Based on the

interaction with people

and things

affective

understanding

Based on the feelings of

pleasure and

displeasure

Fig. 1 Affect-based model of (literary) comprehension

\section{Didactic conclusions}

As soon as text comprehension is conceived not as the rule-guided transformation of a complex of signs into a mental structure, but as a physically and affectively determined process, fundamentally different focal points for school education emerge, especially for the native language teaching. The direction of such didactic shifts in focus is briefly indicated below.

\subsection{On the relationship between ('pragmatic') action and ('referential') language comprehension}

Since the first PISA study - in the range of German-speaking countries - German as a teaching subject in particular has been given responsibility for developing sufficient reading skills. Competence-oriented textbooks respond to this requirement by giving broad scope to the teaching of suitable reading strategies. Such word processing tools are intended to help students with reading difficulties, in particular, to systematically or strategically trace the content and message of texts - for example by asking questions about text passages, summarizing them into a heading, underlining and marking them, or anticipating the further course of the text through well-founded assumptions (cf. a systematic overview in Rosebrock/Nix 2008, p. 81 f.). Reading strategies should be used, in particular, for specialist texts; increasingly, however, a strategically directed reading of literary texts is also didactically contoured and recommended (see last Rosebrock 2018).

There is nothing to be said against the attempt to systematically teach and practice reading strategies in language classes. However, looking at the above considerations on language and reading comprehension calls for some skepticism about the scope and sustainability of such reading strategy programs. Reading and comprehension, it has 
been said, is not a reworking of sign complexes into mental representations by means of suitable algorithms. Instead, they derive meaning and meaningfulness from the sphere of the acting and experiential relationship between a subject and their world. Reading- and textual comprehension ought to be learned as a cultural technique - that much is clear. But all comprehension is based on bodily interaction and finds its meaningful point of reference only there, which is why it would be didactically misguided to place too much emphasis on an isolated text comprehension lesson. Before the understanding of a text about a certain subject matter comes the understanding of the subject matter itself, and the lively interest in tangible objects promotes the understanding of such texts more than any reading strategy program. ${ }^{11}$ It is to be assumed that so-called students 'with reading disabilities' and 'educationally alienated' ones do not only come from 'less literate', but above all, from low-stimulus environments in terms of the possibilities for body-bound experiences with a multifaceted environment. Here, above all, it is necessary to start in the classroom. Teaching text comprehension always means, first and foremost: establishing access to a 'world comprehension'. ${ }^{12}$

\subsection{Affective comprehension as a guide for educational processes}

School-based and increasingly university-based learning is geared towards curricula and competency criteria. These are set; it is up to the learners and teachers to achieve such learning goals. If they should face affective difficulties in this respect, i.e., if the pupils, students, teachers or university lecturers should lose their desire and interest to acquire or impart the required competences - then this is above all their personal problem. They are then required to motivate themselves with appropriate techniques that is, improve their impaired affective balance in order to achieve their goals. The affect is thus subject to the target; at least, it is compelled to be subject to the target.

Usually, this will be done in such a way that extrinsic objectives take on the role of the motivational medium: the prospect of a good grade, the graduation essential for social advancement and a satisfactory lifestyle, the salary, the next career step. Not infrequently, it is the overcoming of affective resistance that is supposed to have a motivating effect: one has mastered a particularly difficult challenge, which ensures a sense of achievement, even though the learning objects remain alien. Because the basic affect is negative, the successful overcoming thereof has a secondary positive effect. Here, too, is it the case that affective priming determines the learning process.

However, for the goal of education for maturity, such a revaluation and extrinsic overwriting of negative affects is a very problematic approach. It makes more sense to pay attention to and take seriously the negative affects that can arise when implementing educational policy requirements. The question should not be: 'What should I do, and how do I motivate myself to do so if I don't want to?', but rather: 'What's causing me to not want to? Is there something wrong with me — or with the

\footnotetext{
${ }^{11}$ Cf. Sadoski 2018, p. 343: "[T] $h e$ application of embodied theories to reading comprehension instruction largely involves the provision of learning contexts that are rich enough to evoke simulations of concrete experiences even when the subjects are relatively abstract."

${ }^{12}$ Only in a footnote I'd like to raise the question of what consequences there may be for the development of cognitive abilities when children are confronted with two-dimensional digital environments at a very early and very far-reaching stage; especially if it comes at the cost of rich body-mediated stimuli.
} 
target imposed on me? Do I have to adapt, or are the social framework conditions to be questioned? What do the others say?' This would be the beginning of an actually rational social discourse, which is rational precisely because it considers the affective foundation of all comprehension and learning. To push away negative affects, to bring oneself and others in line with targets by using suitable motivational techniques, on the other hand, appears as irrational, immature behaviour that unwittingly leaves the sociopolitically decisive values to superordinate authorities without. Sapere aude, Kant's motto of the Enlightenment, does not simply mean 'dare to know', but more originally and literally: 'dare to taste', which in turn means 'dare to feel'. Because sensation and affect form the basis - not only of comprehension - but of every mature and responsible rationality.

\subsection{Literature teaching in the context of the divide between affects and target-meeting: Empirical evidence}

What impact the advanced-stage division of labour between the administrative imposing of competency requirements and their meeting by learning groups may have on everyday teaching of language and literature: this is what initial results of a study conducted by a research group led by Christian Dawidowski show, in a preliminary fashion (cf. Dawidowski 2016; Stolle 2016). Dawidowski et al. conducted a study of literature classes at a secondary school in Germany - classes geared towards the high-school leaving exam with compulsory national regulations right down to the selection of books. Goethe's Iphigenie auf Tauris and Thomas Mann's Buddenbrooks were read and worked with in the relevant highschool courses; in a pre-test phase, the research group produced videos of individual lessons and conducted narrative interviews with students and with the teacher, regarding their reading-related socialization and reading preferences (cf. Dawidowski 2016, p.162). It turned out that the teacher, as well as the learners, drew a sharp line between compulsory and recreational reading:

Accordingly, the informants did not describe any transition areas between private and non-private reading modes. The private reading materials and modes are therefore hardly part of literary education; they are placed in clear contrast to the official educational discourse, both temporally (childhood) and spatially (school). Thus, there are no examples of an emotional internalization of the 'official' material. $^{13}$

This does not mean, however, that compulsory reading is not emotionally connoted; affects also play a role in situations where seemingly only a task is being carried out in a sober manner. The interviewed German teacher strikingly often uses the verb have to in connection with the learning material in school and (as is apparent) at university ("you have to work with the texts; you have to understand them", "of course, I also

\footnotetext{
13 "Dementsprechend formulierten die Informanten keine Übergänge zwischen privaten und nicht-privaten Lesemodi. Die privaten Stoffe und Modi sind somit kaum Bestandteil literarischer Bildung, sie werden sowohl zeitlich (Kindheit) als auch räumlich (Schule) in deutlichem Kontrast zum offiziellen Bildungsdiskurs angesiedelt. Damit sind keine Beispiele eines auch emotionalen Sich-Anverwandelns des,offiziellen 'Stoffes vorhanden." (Dawidowski 2016, p. 164)
} 
have to work with them, whether or not I really want to read them". ${ }^{14}$ She has experienced that "reading is not always pleasant" and "in some ways exhausting", and categorically opposes "private leisure reading" to "literature", which she also describes to the students as "not easy to swallow". ${ }^{15}$ Literary reading here appears to be a difficult, resistant, strenuous task - a duty - which has nothing in common with the enjoyment and relieving effect of childlike-reading or reading for pleasure ("not always as I [...], in childhood and adolescence, experienced that reading is not always just pleasant and is not always for just winding down"). ${ }^{16}$ In this undeniably negative connotation of literary reading, the teacher coincides with her students. In the interviews and recorded lessons, they fatalistically say, "you just have to get used to it"17 (i.e., the school reading list); Goethe's drama is first welcomed with the sarcastic remarks: "Oh yes, great, classic, Iphigenia"; there is a presupposed consensus that "verse form is, of course, totally deterring"18; and, when it comes to the Buddenbrooks, the overwhelming number of "700 pages" is emphasized repeatedly (Dawidowski 2016, pp. 166 and 167).

Interestingly enough, it is exactly this specific resistance of literary texts that is positively revalued by the group and teacher. Precisely because the task is so difficult, its mastery promises a unique experience of success. The "verse form" may, at the beginning, be "totally deterrent, of course", but after the in-depth study of Goethe's dramatic text, it is "no longer a problem at all"19; furthermore, the joint struggle with Mann's 700 pages grants the readers a proudly relieved and intense sigh of "yes, I did it". ${ }^{20}$ It is especially the teacher who uses the motivational pattern of the great challenge to be overcome. For her, it even makes sense to dramatize the difficulty of the literary text. It can never seem to be resistant or even frightening enough - the promised experience of successful overcoming of the challenge will be all the greater. "I tell you," she lets her students know, "that this is no bedtime-reading material. It really requires absolute concentration, not only of you, but of me, too" (Stolle 2016, p. 94). ${ }^{21}$ With the label "no bedtime-reading material", she makes it clear that she would in no way grant Goethe's drama access to her protected private space; at the same time, she emphasizes that conquering such reading material requires a well-rested and highly concentrated mind. The motivational scheme here is borrowed from athletic discourse. Extreme challenges are there to be overcome; if you face them, you will be proud of the performance accomplished. Thomas Mann's saga looms before the despondent literary novice like a 700-page mountain, but the roped party, under mountain-savvy

\footnotetext{
14 "man muss mit den Texten arbeiten man muss sie verstehen", "auch berufsbezogen muss ich natürlich auch ob ich will oder nicht ganz viel lesen" (Stolle 2016, 93 f.).

15 "da habe ich dann schon gemerkt dass [...] Lesen nicht immer nur angenehm ist"; "das alles ist ja in gewisser Weise auch anstrengend"; "Private leichte Kost auch Literatur alles"; "Also für mich ist das auch kein, keine leichte Kost, sag 'ich mal.” (Stolle 2016, p. 94)

16 "nicht immer nur wie ich es [...] in der Kindheit und Jugend erfahren habe dass Lesen nicht immer nur angenehm ist und nicht immer nur dem Abschalten dient" (ibid.).

17 "[m]an muss sich halt dran gewöhnen"(Dawidowski 2016, p. 163).

18 “oh ja super, klassisch, Iphigenie", "die Versform ist natürlich total abschreckend" (Stolle 2016, p. 94).

19 "die Versform is natürlich total abschreckend, aber [...] am Ende muss ich sagen, dass die Versform gar kein Problem mehr ist, wenn man sich 'n bisschen damit beschäftigt." (Stolle 2016, p. 94)

20 "ja geschafft" (Dawidowski 2016, p. 166).

21 " $[\mathrm{I}] \mathrm{ch}$ sag ja, es ist keine Gute-Nacht-Lektüre. Es verlangt wirklich absolute Konzentration, nicht nur von euch, von mit genauso." (Stolle 2016, p. 94)
} 
leadership, will succeed in taking everyone along with them to meet these dizzying heights. The classical verse form is "of course" as "deterrent" for the literary beginner as the rugged rock face for the inexperienced climber; but after putting to use patience, know-how, and tough willpower, it turns out in retrospect that everything is "no longer a problem" after all.

Here, the necessary motivation for working on literary text stems from - or is supposed to, at least - from the revaluation of negative affects into secondary positive ones. Because a task is difficult, dissuasive, and challenging, its successful completion is meant to provide an experience of success that is the greater for it. This affective dialectic is supported by making reference to valuations by third parties, namely by instances considered socially competent and relevant; these valuations are adopted unchecked. Dawidowski speaks of the "impression of a break between subjectivepersonal access to the work and the accreditation resulting from its social relevance". ${ }^{22}$ Reading in school is regarded by one of the interviewed students to be equally "something to get used to" and "very important"23; the teacher considers literary texts, which she differentiates from "light reading" (loc.cit.), as mentioned, to be "particularly pedagogically valuable" 24 ; in the classroom discussion she raises the question as to how far Thomas Mann's debut novel can be described as "of literary value" (ibid., p. $166),{ }^{25}$ and does not question the short student response that "only the fact that it deserved a Nobel Prize"26 stands for the special value of the work. In general, canonization decisions resulting from the curriculum - and as supposedly consensual value judgements - are adopted without reflection ("all the dramas that we have also read before, I find, should simply be part of an advanced German course - or at least one should know a little about them"; "Goethe is a must-know; well, with an advanced course, one expects that knowledge somewhere, too"). ${ }^{27}$ The presupposed, socially determined 'having to' and 'being expected to' are adapted without any hesitation; there is no discursive relation to one's own affectively charged experience of reading.

Dawidowski (2016, p. 162 and passim) points out several times that the data collected in the pre-test are too few to draw hasty generalizing conclusions. This, of course, must be all the more true of the remarks in the present paper, which in turn only refer to the narrow extract of student and teacher statements which the two publications present. So, that the selective observations from the German advanced course are in any way representative of literary learning against the background of competence orientation and standardized final exams cannot be legitimately asserted; at least the observations presented by Dawidowski et al. illustrate the subsequent considerations vividly.

What must be noticed about the cited snapshots from class is the peculiar discrepancy between the meeting of curricular targets on the one hand, and missing the point of having a literary and aesthetic class, on the other hand. If Thomas Mann's and

\footnotetext{
22 "Eindruck eines Bruchs zwischen subjektiv-persönlichem Zugang zum Werk und der Beglaubigung durch seine soziale Relevanz" (Dawidowski 2016, p. 166).

23 "Man muss sich halt dran gewöhnen also, wie gesagt im Kinderalter ist ja sehr wichtig." (ibid., p. 163)

24 "pädagogisch besonders wertvoll" (ibid.).

25 "literarisch wertvoll" (Dawidowski 2016, p. 166).

26 "allein die Tatsache, dass es halt 'n Nobelpreis verdient hat" (ibid.).

27 “die ganzen Dramen, die wir auch vorher gelesen haben, find ich, sollte man im Deutsch LK auch einfach mal gelesen haben oder zumindest so'n bisschen darüber Bescheid wissen” (ibid.); "Goethe muss man kennen, also bei "nem Leistungskurs erwartet man das ja irgendwo auch" (ibid., p. 168).
} 
Goethe's texts are perceived as heavy, resilient and challenging even after their indepth study ("I did it", as mentioned above), one must ask to what extent they can be regarded as adequately received and understood. "Kunst soll keine Schulaufgabe und Mühseligkeit sein, keine Beschäftigung contre cœur", says Thomas Mann on the occasion of his Introduction to the 'Zauberberg', given in front of American students, "sondern sie will und soll Freude bereiten, unterhalten und beleben, und auf wen ein Werk diese Wirkung nicht übt, der soll es liegenlassen und sich zu andrem wenden" (Mann 1960, p. 610). ${ }^{28}$ From this point of view, all those involved in the documented class, especially the teacher, too, in an almost grotesque way miss the point of the meaning and essence of literary reading, as one of the authors covered understands it, incidentally. The conception of literature as an overcoming of laborious school tasks, usually undertaken against personal affective inclination (contre cour), in an alarming way contradicts the position that it wants to bring joy, it should entertain and enliven, and that it should only be taken up on the basis of absolute voluntariness. One has to ask whether a misuse of literary texts exists when the main interest in a book is whether or not "it's good for the standardized high-school leaving exam" (from a student statement), ${ }^{29}$ or when its verse form is perceived solely as a barrier to comprehension. Blank verse was not invented primarily for deterrence, after all, but can provide aesthetic pleasure; and if students, just before graduating from a German high-school, have no idea or experience of such phonetic beauty of literary speech, in the strict sense they understand nothing of meter and verse.

The question can only be broached here and, in the absence of sufficient empirical evidence, not answered: whether the misappropriation, indeed prevention, of literary learning observed in this example could also be attributed to more recent school policy frameworks. In any case, the noticeable athletic mindset - literary reading as a strategic challenge that mobilizes all intellectual forces to overcome an extreme challenge correlates strikingly with a spirit of competition and improved performance that has shaped educational policy discourse in the German-speaking world since the first PISA study. ${ }^{30}$ Competences are to be assessed and measured; they are to grow as steadily as possible in accordance with the logic of the economy, and in a nationwide crosssection, of course; they are to secure a place in the top tier for the nation in question, as they would in competitive sports: this seems to be the consensus and will be argued for not least by making reference to the needs of the pupils themselves, whose individual growth in competence is assumed to be in their personal and economic interest.

One may wonder, however, whether the necessary effort for a collective increase in performance in the school's core competences - for example through all-day schooling, often supported by private tutoring - really meets the present and future needs of each individual child, who would perhaps prefer to paint, play an instrument, play sports,

\footnotetext{
28 "Art is not supposed to be considered a labourious school task, not an occupation contre cœur. Instead, it should and wants to bring joy, it should entertain and enliven; to those who do not experience such an effect from a work, let them lay it down and turn towards something else."

29 "dass es für's Zentralabitur gut is" (Dawidowski 2016, p. 167).

${ }^{30}$ Former Austrian Minister of Education Sonja Hammerschmidt commented on the nationwide, rather disappointing, results of the recent survey cycle, saying that the result was "unacceptable", that "average" was "not a desirable result" to her, and that "the goal must rather be that Austria reach a top-ten PISA position among OECD countries" (cf. Der Standard from Dec. 6th, 2016, "Pisa-Ergebnisse sind für Hammerschmidt inakzeptabel" ["PISA Results are Unacceptable for Hammerschmidt"]).
} 
play games or simply be idle. In any case, the question that needs to be examined more closely is how the tightening of the competence screw through the setting of standards and specifications for standardized final examinations actually affects learning, particularly literary learning. The selective insight into the classes of the advanced German course points to the fact that it is precisely the increase in educational administrative pressure that leads to misguided forms of alienated learning, disconnected from individual affective states. Those who demand an increase in performance across the board will receive little more than just the required performance. Typically, however, this happens without the inner participation of the personality and by using all means to fulfill performance requirements, since they are economically justified, in a manner that is as cost-effective as possible; i.e., in a merely formal, not infrequently superficial manner. Genuinely literary-aesthetic learning, however, must necessarily be counteracted and compromised by an educational discourse geared towards success, improved performance and economic efficiency.

\section{Conclusion and outlook}

The considerations made here took as a starting point the educational policy demand for a model of competence of text comprehension, which should make it possible to operationalize, measure and systematically increase comprehension accomplishments and competences. The model of classical cognitivism theory appeared particularly suitable for this purpose, since it determines comprehension as a rule-guided transfer of a sign complex into a mental representation. The critique of the aporetic character of such representationalism then led to a review of recent concepts of understanding from the area of Embodied Cognition, according to which all mental operations are embedded in physical interaction processes. Comprehension does not, in this sense, mean building semiotic models and storing them in the brain, but rather letting physical primary experiences be reproduced in a trial-action fashion. This approach was subsequently considered in relation to the role of subjectivity and affect. Physical experiences, it has been said, are meaning-generating because, first of all, they exhibit a subjectively perceived affective valence between pleasure and suffering. The beginning of all understanding would therefore have to be located within the emotional sphere.

Such a conception of understanding, however, does not have much to do with the educational policy endeavour to make learner-specific competences available and to systematically increase them. On the contrary, if you take the emotional priming of all understanding and learning processes seriously, learning and understanding always mean cultivating an alert ear for affective undertones, needs and irritations. The development of such mindfulness should thus become the core concern of education and teaching, in the sense of Ruth Cohn's Störungen, die Vorrang haben [disturbances that take precedence] (cf. Cohn 1997, p. 122). Possible individual states of being disturbed in the face of a powerful socio-political optimization and enhancement imperative could thereby become the starting point of a discursive movement which ultimately questions, and indeed, precisely sabotages this growth- and improvement mechanism. This might not be a welcomed prospect for current education policy; but for the 
project of education towards maturity, democratic participation, sensitivity to the demands of the self, others and the environment, an affectively sound school of understanding promises a lasting gain.

Acknowledgments The English translation of this paper was carried out by innsbruck university innovations $\mathrm{GmbH}$ with the kind support of the Faculty of Teacher Education and the Institut für Fachdidaktik, University of Innsbruck.

Funding Information Open access funding provided by University of Innsbruck and Medical University of Innsbruck.

Open Access This article is licensed under a Creative Commons Attribution 4.0 International License, which permits use, sharing, adaptation, distribution and reproduction in any medium or format, as long as you give appropriate credit to the original author(s) and the source, provide a link to the Creative Commons licence, and indicate if changes were made. The images or other third party material in this article are included in the article's Creative Commons licence, unless indicated otherwise in a credit line to the material. If material is not included in the article's Creative Commons licence and your intended use is not permitted by statutory regulation or exceeds the permitted use, you will need to obtain permission directly from the copyright holder. To view a copy of this licence, visit http://creativecommons.org/licenses/by/4.0/.

\section{References}

Christmann, Ursula (2010). Lesepsychologie. In Michael Kämper-van den Boogaart, Kaspar H. Spinner (Eds.), Lese- und Literaturunterricht. Teil 1 (pp. 148-200). Baltmannsweiler: Schneider Hohengehren (= Deutschunterricht in Theorie und Praxis. Handbuch zur Didaktik der deutschen Sprache und Literatur in elf Bänden. Band 11/1).

Cohn, Ruth C. (131997). Von der psychoanalyse zur themenzentrierten Interaktion. Stuttgart: Klett-Cotta.

Dawidowski, Christian (2016). Literarizität und literarische Bildung im Literaturunterricht: Eine empirische Annäherung. In J. Brüggemann, M.-G. Dehrmann, \& J. Standke (Eds.), Literarizität. Herausforderungen für Literaturdidaktik und Literaturwissenschaft. Baltmannsweiler (pp. 155-168). Schneider Hohengehren: Baltmannsweiler.

Della Putta, Paolo (2018). Embodied semantics and the Mirror neurons: Past research and some proposals for the future. In A. Baicchi, R. Digonnet, \& J. Sandford (Eds.), Sensory Perceptions in Language, Embodiment and Epistemology. Studies in Applied Philosophy, Epistemology and Rational Ethics (Vol. 42). Cham: Springer.

di Pellegrino, G., Fadiga, L., Fogassi, L., Gallese, V., \& Rizzolatti, G. (1992). Understanding motor events: A neurophysiological study. Experimental Brain Research, 91(1), 176-180.

Eco, Umberto (1976). A theory of semiotics. Bloomington: Indiana University Press.

Jakobson, Roman (1960). Closing Statement: Linguistics and Poetics. In R. Jakobson (Ed.), Style in Language (pp. 350-377). Cambridge: Technology Press of Massachusetts.

Johnson, Mark (1987). The body in the mind. In The bodily basis of meaning, imagination, and reason. Chicago \& London: The University of Chicago Press.

Johnson, Mark (2007). The meaning of the body. Aestetics of Human Understanding. Chicago: The University of Chicago Press.

Kant, Immanuel (121992) [1790]. Kritik der Urteilskraft. Werkausgabe in 12 Bänden. Band X. Ed. by Wilhelm Weischedel. Frankfurt a.M.: Suhrkamp.

Klieme, Eckhhard, et al. (2003). Zur Entwicklung nationaler Bildungsstandards. Eine expertise. Bonn: BMBF.

Lakoff, George \& Johnson, Mark (1980). Metaphors we live by. Chicago et al.: The University of Chicago Press.

Mann, Thomas (1960) [1939]. Einführung in den ,Zauberberg‘. Für Studenten der Universität Princeton. In: Thomas Mann, Gesammelte Werke in dreizehn Bänden, vol. 9 (pp. 602-617). Frankfurt a.M.: S. Fischer. 
Odendahl, Johannes (2018). Literarisches Verstehen. Grundlagen und didaktische Perspektiven. Berlin: Peter Lang.

Pulvermüller, Friedemann (2008): Grounding language in the brain. In M.de Vega, A. Graesser, \& A. Glenberg (Ed.), Symbols and embodiment: Debates on meaning and cognition (pp. 85-116). Oxford: Oxford University Press.

Richter, Tobias, \& Christmann, Ursula (2002). Lesekompetenz: Prozessebenen und interindividuelle Unterschiede. In Norbert Groeben, Bettina Hurrelmann (Ed.), Lesekompetenz. Bedingungen, Dimensionen, Funktionen (25-58). Weinheim und München: Juventa.

Rosebrock, Cornelia (2018). Strategien des ästhetischen Lesens. Literarisches Lernen in rezeptionsästhetischer Perspektive. In D. Scherf \& A. Bertschi-Kaufmann (Eds.), Ästhetische Rezeptionsprozesse in didaktischer Perspektive (pp. 14-27). Beltz Juventa: Weinheim.

Rosebrock, Cornelia, \& Nix, Daniel (2008). Grundlagen der Lesedidaktik und der systematischen schulischen Leseförderung. Baltmannsweiler: Schneider Hohengehren.

Sadoski, Mark (2018). Reading comprehension is embodied: Theoretical and practical considerations. Educational Psychology Review, 30(2), 331-349.

Schleiermacher, Friedrich D. E. (1977). Hermeneutik und Kritik. Ed. by Manfred Frank. Frankfurt a.M.: Suhrkamp.

Stolle, Angelika (2016). Fokus Lesen und Schule: Lehrer und Literaturunterricht. In Christian Dawidowski (Ed.), Literaturdidaktik Deutsch. Eine Einführung. Paderborn: Ferdinand Schöningh.

van Dijk, Teun A., \& Kintsch, Walter (1983). Strategies of Discourse Comprehension. New York et al.: Acad. Press.

Winkler, Iris (2011). Aufgabenpräferenzen für den Literaturunterricht. Eine Erhebung unter Deutschlehrkräften. Wiesbaden: VS Verlag für Sozialwissenschaften.

Zabka, Thomas (2012). Didaktische Analyse literarischer Texte. Theoretische Überlegungen zu einer Lehrerkompetenz. In Daniela A Frickel, Clemens Kammler, \& Gerhard Rupp (Ed.), Literaturdidaktik im Zeichen von Kompetenzorientierung und Empirie. Perspektiven und Probleme (pp. 139-162). Freiburg i.Br.: Fillibach.

Publisher's note Springer Nature remains neutral with regard to jurisdictional claims in published maps and institutional affiliations.

\section{Affiliations}

\section{Johannes Odendahl ${ }^{1}$}

1 Universität Innsbruck, (Institut für Fachdidaktik, Didaktik des Unterrichtsfachs Deutsch), Innrain 52d, A6020 Innsbruck, Austria 